\title{
Analysis of the Impact of Sino-US Trade Friction on China's Major Industries Based on Dynamic GTAP Model
}

\author{
Lili Zhang ${ }^{1, \mathrm{a},{ }^{*}}$, Chuncheng Zhang ${ }^{1, \mathrm{~b}}$, Wei Tang ${ }^{1, \mathrm{c}}$ and Shanshan $\mathrm{Wu}^{1, \mathrm{~d}}$
}

\author{
${ }^{1}$ State Grid Energy Research Institute Co., Ltd., Beijing, China \\ zhanglili@amss.ac.cn, ${ }^{b}$ zhangchuncheng@sgeri.sgcc.com.cn, ${ }^{c}$ tangwei@sgeri.sgcc.com.cn, \\ ${ }^{d}$ wushanshan@sgeri.sgcc.com.cn \\ *Corresponding author
}

\begin{abstract}
This paper quantitatively analyzes the impact of Sino-US trade friction on China's economy and major industries by dynamic GTAP model. The research shows that although the US can reduce trade deficit in short-term under the Sino-US trade friction escalation scenario. The reduction is achieved by a faster decline in imports than that in exports, while its consumption, investment, employment, and economic growth will be damaged. This is contrary to Trump's intention to increase trade surpluses through trade protection measures to drive economic growth and employment. For China, there is little impact on China's traditional highenergy-consuming industries in Sino-US trade friction escalation scenario, which is driven by China's supplyside structural reform. The traditional industry has achieved remarkable effect in capacity reduction, and the growth rate of exports has declined. China is in a critical period of transition between old and new industry. The rapid development of high-tech industries has become a new power for economy growth and an important starting point for China to achieve high-quality development. The escalation of trade friction will have a greater negative impact on the development of high-tech industry. The trade friction mitigation scenario can achieve a win-win situation between China and the US, providing a steady environment for the development of China's high-tech industry and achieving high-quality development.
\end{abstract}

Keywords: dynamic GTAP model, Sino-US trade friction, tariff barriers, economic structure

\section{INTRODUCTION}

The US became aware of the dangers of asset bubbles and industry hollowing via the financial crisis in 2008. Then the US implemented the "re-industrialization" policy, "Innovation Strategies", "National Export Plans", and "Manufacturing Promotion Act". Since Trump took office, he has taken several policies to revitalize economy, increase employment, and attract overseas capital to return. He also regards trade which causes the US trade deficit as "unfair trade" and attempts to reduce the fiscal deficit and trade deficit through trade protection measures, thus protecting the industry development of the US. As the largest trading partner of the US and the largest source of trade deficit, the trade protection measures against China continued to escalate. Since the Sino-US trade friction occurred in March 2018, both China and the US were affected. The implementation of trade barriers by the US to China's hightech industries will become the focus of trade friction. In the future, more trade protection tools may be used to further promote trade friction. At the same time, considering that China is in the critical period of supply-side structural reform, new and old growth power conversion, and industrial restructuring, It makes sense to do research on the impact of Sino-US trade friction on China's economy and industrial structure, and explore China's reasonable and effective strategies.

Many scholars have analyzed the impact of trade friction on the economies of China. Some scholars believe that the impact of Trump trade protection measures on economy of China is limited. Huang Xinmiao ${ }^{[1]}$ pointed out that as China's links with new markets strengthened and the added value of products exported to the United States increases, China will weaken the impact of US tariff increases. Wang Kaile $^{[2]}$ pointed out that China's economy is in a period of restructuring and restructuring. China no longer relies on exporting cheap goods and labor to promote economic development as 10 years ago. Other scholars believe that Trump's trade protection measures have a large negative impact on the Chinese economy, and provide an opportunity for China's economic transformation at the same time. Han Bett $^{[3]}$ pointed out that China's exports to the United States will be largely restricted, which will have serious impact on China's economy. At the same time, this also provides an opportunity for the transformation of China's economy and drive China's economy growth shifts from export to stimulating domestic consumption and expanding domestic demand. Some scholars have quantitatively analyzed the impact of Sino-US trade friction. Wu Jiansheng ${ }^{[4]}$ constructed a CGE model to measure the impact of Trump's new economic policies on China's economy. If the United States imposes a high tariff of $45 \%$ on goods imported from China, it will lead to a decline in China's exports and GDP by $4.6 \%$ and $0.6 \%$ respectively. Wang Jiaqiang ${ }^{[5]}$ pointed out that if the United States imposes a 5\% uniform tariff on China, it will reduce China's total exports to the United States by about $7 \%$.

The current quantitative analysis of the impact of Sino-US trade friction on China's economy is mainly on the impact of 
needs, the GTAPAgg9 software developed by Purdue University's Global Trade Research Center is used to divide 140 countries into 11 regions (countries) (Table 3), and aggregated 57 industrial sectors into 30 industrial sectors (Table 4). Therefore, this paper uses the Global Trade Analysis Project (GTAP) developed by Purdue University and its latest edition (2011) global multi-sector input-output database to quantitatively analyze the impact of trade friction on China's economy and industrial structure under different trade friction scenarios. In the end, China's reasonable and effective strategies are explored through policy simulation.

\section{MODEL METHOD AND DATA PROCESSING}

\subsection{Model}

The GTAP model developed by Purdue University is a multi-state and multi-sector computable general equilibrium model based on economic theory. In the GTAP framework, a sub-model that can describe the production, consumption, and government expenditures of each country (or region) is first established, and then the sub-models are linked into a multi-state and multi-sector general equilibrium model through international trade. The impact of policy changes on production, import and export, commodity prices, factor supply and demand, factor remuneration, gross domestic product, and social welfare levels in various sectors of the country can be discussed. GTAP has proven to be an effective tool for quantifying trade issues. This paper uses dynamic GTAP to measure the impact of Sino-US trade friction on China's economy and major industries.

\subsection{Data Processing}

This paper uses the latest dynamic GTAP model and the ninth edition database, which is based on the social accounting matrix of each country in 2011, and contains 57 industrial sectors in 140 countries (regions). Due to research

Table 1 Comparison of trade costs between China and major economies in 2017

\begin{tabular}{c|c|cccc}
\hline & Non-tariff cost & China & US & $\begin{array}{c}\text { Asia- } \\
\text { Pacific }\end{array}$ & $\begin{array}{c}\text { OECD high } \\
\text { income countries }\end{array}$ \\
\hline \multirow{3}{*}{ Export } & Boundary compliance (hours) & 25.9 & 1.5 & 55.9 & 12.7 \\
& Boundary compliance (\$) & 484.1 & 175.0 & 387.5 & 149.9 \\
& Document compliance time (hours) & 21.2 & 1.5 & 68.2 & 2.4 \\
& Document compliance (US\$) & 84.6 & 60.0 & 112.1 & 35.4 \\
\hline \multirow{3}{*}{ Import } & Boundary compliance (hours) & 92.3 & 1.5 & 70.5 & 8.7 \\
& Boundary compliance (\$) & 745.0 & 175.0 & 431.0 & 111.6 \\
& Document compliance time (hours) & 65.7 & 7.5 & 65.6 & 3.5 \\
& Document compliance (US\$) & 170.9 & 100.0 & 111.4 & 25.6 \\
\hline
\end{tabular}

Source: World Bank, Doing Business Database

\subsection{Impact on Macroeconomics of China and US}

Under the trade friction escalation scenario, China's consumption and fixed capital formation will fall by $0.42 \%$ and $1.87 \%$ by 2020 . At the same time, China's exports and

\section{SCENARIO \\ AND \\ SIMULATION RESULTS}

\subsection{Scenario setting}

Basic scenario: Assume that the original policies of all countries will continue to be implemented. The GTAP database is updated by dynamic recursive method. The growth rate of GDP and population in major countries and regions are calibrated by reference to the International Monetary Fund, World Bank, and United Nations. The data is calibrated to 2020 to form the basic scenario.

Trade friction escalation scenario: The US imposes a 25\% import tariff on Chinese ferrous metals, automobiles and parts, transportation equipment, electronic products, mechanical and electrical products. China imposes a $25 \%$ import tariff on US agricultural products, meat products, food processing products, automobiles and parts, transportation equipment, and chemical products.

Trade friction mitigation scenario: According to framework agreement between China and the United States on bilateral trade issues, China will take effective measures to substantially reduce the US trade deficit with China and increase imports of US agricultural products and energy, create favorable conditions to expand trade between China and US in manufacturing and services. China may increase imports from US by cutting certain tariffs or by increasing the ease of imports from US. The model assumes that degree of convenience China's import of agricultural products, meat products, food processing products, energy products, automobiles and parts, transportation equipment, and chemical products from the US will increase by $25 \%$.

imports will fall by $1.25 \%$ and $4.36 \%$. Domestic demand will fall due to the lack of domestic consumption and investment, China's imports will fall more than exports, and the trade surplus will increase by US $\$ 32.63$ billion. By 2020 , China's GDP growth rate will drop by 0.35 percentage points Affected by the decline in exports and domestic demand, employment in China will decline by $0.88 \%$, which is equivalent to a reduction of 6823.3 thousand jobs. While 
trade friction reduced China's exports, it increased its domestic supply to China. At the same time, due to insufficient domestic demand, China's CPI will fall by 0.89 percentage points. For the United States, consumption and fixed capital formation will fall by $0.2 \%$ and $4.42 \%$ by 2020 , exports and imports will fall by $1.81 \%$ and $4.36 \%$. For the lager fall in imports, its deficit will decrease by $\$ 81.293$ billion. By 2020, GDP growth rate of the US will drop by 0.28 percentage points. The jobs will fall by $0.45 \%$, which is equivalent to a reduction of 699 thousand jobs. Affected by insufficient domestic demand, the CPI will fall by 0.32 percentage points.

Under the trade friction mitigation scenario, China's consumption and fixed capital formation will increase by $0.44 \%$ and $0.87 \%$ by 2020 . Meantime, China's exports and imports will increase by $1.04 \%$ and $1.85 \%$. Due to the increase in domestic consumption and investment, domestic demand is sufficient. China's imports will increase more than exports, and the trade surplus will decrease by US $\$ 16.7$ billion. By 2020, China's GDP growth rate will increase by 0.48 percentage points. Affected by the rise in exports and domestic demand, employment in China will increase by $0.52 \%$. This is equivalent to an increase of 4073.3 thousand jobs. Affected by the cost reduction from the increase in import facilitation, the CPI will fall by 0.18 percentage points. For the US, its consumption and fixed capital formation will increase by $0.14 \%$ and $1.14 \%$ by 2020 , and exports and imports will increase by $0.48 \%$ and $1.69 \%$ respectively. Since the increase in imports is greater than that in exports, the deficit will gain an increase of $\$ 15.229$ billion. By 2020, GDP growth rate of the US will increase by 0.04 percentage points. The employment will increase by $0.15 \%$. This is equivalent to an increase of 233 thousand jobs. Affected by strong domestic demand, US CPI will rise by 0.75 percentage points.

Table 2 The impact of trade friction on China and US

\begin{tabular}{ccccc}
\hline \multirow{2}{*}{2020} & \multicolumn{2}{c}{ Trade Friction Escalation Scenario } & \multicolumn{2}{c}{ Trade Friction Mitigation Scenario } \\
\cline { 2 - 5 } & China & US & China & US \\
\hline GDP & -0.35 & -0.28 & 0.48 & 0.04 \\
Consumption & -0.42 & -0.22 & 0.44 & 0.14 \\
Investment & -1.87 & -5.00 & 0.87 & 1.14 \\
Export & -1.25 & -2.60 & 1.04 & 0.48 \\
Import & -4.36 & -5.45 & 1.85 & 1.69 \\
Trade Surplus & 326.30 & 812.93 & -167.00 & -152.92 \\
Employment & -0.88 & -0.45 & 0.52 & 0.15 \\
CPI & -0.89 & -0.32 & -0.18 & 0.75 \\
\hline
\end{tabular}

Note: Change of the cumulative rate (\%) by 2020 compared to the basic scenario.

Trade surplus is change compared to basic scenario (\$100 million).

Data source: GTAP model simulation results.

\subsection{Impact on Macroeconomics of Other Countries}

Under the trade friction escalation scenario, due to the trade substitution effect, China and US will imports more from other countries, thereby stimulating economic growth of other countries. As shown in Table 3, countries and regions that benefit greatly include Mexico, South Korea, ASEAN, Japan, Latin America, and European Union. In terms of welfare, welfare in China and US will decrease by 616.54 and 36.191 billion dollars. Meantime, the welfare of other countries and regions will increase on average. But the overall welfare level will still fall by 32.17 billion dollars globally.

Under the trade friction mitigation scenario, due to the squeeze-out effect, the deepening trade cooperation between China and US will cause less imports from other countries, thereby reducing economic growth in other countries. As shown in Table 3, countries and regions with greater damage include South Korea, ASEAN, Latin America, Japan, Canada, European Union, and Mexico. From the perspective of welfare, the welfare will increase by 398.20 billion and 25.786 billion dollars in China and US. The welfare of other countries and regions declined averagely. But for the global perspective, the overall welfare level will rise by 48.265 billion dollars. 
Table 3 The impact of trade friction on other countries

\begin{tabular}{ccccc}
\hline 2020 & \multicolumn{2}{c}{$\begin{array}{c}\text { Trade Friction } \\
\text { Escalation Scenario }\end{array}$} & \multicolumn{2}{c}{$\begin{array}{c}\text { Trade Friction } \\
\text { Mitigation Scenario }\end{array}$} \\
\hline Country & GDP & Welfare & GDP & Welfare \\
\hline China & -0.35 & -61654.25 & 0.48 & 39816.50 \\
US & -0.28 & -36190.75 & 0.04 & 25875.63 \\
EU & 0.06 & 13789.63 & -0.02 & -1239.94 \\
Mexico & 0.56 & 20713.79 & -0.02 & -1072.54 \\
Canada & 0.02 & 509.25 & -0.03 & -1289.45 \\
Japan & 0.08 & 8637.03 & -0.03 & -1914.26 \\
Korea & 0.24 & 5999.78 & -0.10 & -1792.54 \\
Sub-Saharan Africa & 0.06 & 22.34 & -0.01 & -196.05 \\
ASEAN & 0.18 & 9123.66 & -0.05 & -3244.94 \\
Latin America & 0.07 & 2876.56 & -0.04 & -2643.59 \\
Other Countries & 0.07 & 4006.00 & -0.02 & -4033.75 \\
\hline
\end{tabular}

Note: Change of the cumulative rate (\%) by 2020 compared to the basic scenario.

Trade surplus is change compared to basic scenario (\$100 million).

Data source: GTAP model simulation results.

\subsection{Impact on Trade of China and US}

Under the trade friction escalation scenario, the export of China's vehicles and spare parts, electronic equipment manufacturing, machinery and equipment manufacturing will be significantly reduced due to the increase in US tariffs. By 2020, the exports of former three industries will decline by $5.67 \%, 12.20 \%$ and $5.91 \%$ respectively. As the higher tariffs restrict economic growth, domestic demand and factor prices will decline, and exports of other industries will increase slightly. Affected by the increase in China's tariffs, exports of US agriculture, livestock and meat products, food processing industries, motor vehicles and spare parts, transportation equipment manufacturing, chemical rubber and plastic products, and electronic equipment manufacturing will decline significantly. The exports of these seven industries will fall by $6.43 \%, 3.87 \%, 1.64 \%$, $5.20 \%, 6.99 \%, 6.46 \%$ and $12.94 \%$ respectively by 2020 .

Under the trade friction mitigation scenario, US exports of agricultural products, livestock and meat products, natural gas, motor vehicles and spare parts, transportation equipment manufacturing, chemical rubber and plastic products will be significantly affected by China's higher trade facilitation. By 2020, the exports of these six industries will increase by $6.01 \%, 7.97 \%, 10.81 \%, 6.04 \%, 6.70 \%$ and $11.94 \%$ respectively. Correspondingly, the export growth rate of China's agriculture, livestock and meat products, motor vehicles and spare parts, transportation equipment manufacturing, chemical rubber and plastic products, and electronic equipment manufacturing will increase significantly, and will rise by $11.37 \%, 22.32 \%, 3.81 \%$, $41.58 \%$, and $6.72 \%$ by 2020 . 
Table 4 The impact of trade friction on import and export of China and US

\begin{tabular}{|c|c|c|c|c|c|c|c|c|}
\hline \multirow{3}{*}{$\begin{array}{c}2020 \\
\text { Industry }\end{array}$} & \multicolumn{4}{|c|}{$\begin{array}{c}\text { Trade Friction } \\
\text { Escalation Scenario } \\
\end{array}$} & \multicolumn{4}{|c|}{$\begin{array}{c}\text { Trade Friction } \\
\text { Mitigation Scenario } \\
\end{array}$} \\
\hline & \multicolumn{2}{|c|}{ Export } & \multicolumn{2}{|c|}{ Import } & \multicolumn{2}{|c|}{ Export } & \multicolumn{2}{|c|}{ Import } \\
\hline & China & US & China & US & China & US & China & US \\
\hline Agriculture & -1.16 & -6.43 & -13.90 & -4.36 & 4.97 & 6.01 & 11.37 & 4.44 \\
\hline Livestock and Meat Products & 1.48 & -3.87 & -15.80 & -3.21 & 5.68 & 7.97 & 22.32 & 3.76 \\
\hline Coal & 1.58 & -0.44 & -0.82 & 0.08 & -0.19 & -0.66 & 0.11 & 0.47 \\
\hline Oil & 1.68 & 0.48 & -0.73 & -0.30 & -0.83 & -1.00 & 0.35 & 0.52 \\
\hline Natural Gas & -1.55 & -0.37 & 0.47 & -0.96 & 1.83 & 10.81 & 0.78 & 6.88 \\
\hline $\begin{array}{l}\text { Forestry, Fisheries and Other } \\
\text { Mining Industry }\end{array}$ & 0.69 & -0.46 & -0.53 & 1.43 & 0.00 & -0.68 & 0.12 & 0.37 \\
\hline Food Processing Industry & 1.93 & -1.64 & -4.46 & -1.89 & 2.85 & -3.32 & -1.27 & 1.68 \\
\hline Textile and Clothing Industry & 2.93 & 1.19 & -1.67 & -0.91 & 1.90 & -5.45 & -0.67 & 2.35 \\
\hline Leather Industry & 2.63 & 2.90 & -2.27 & -0.08 & 1.66 & -6.51 & -1.15 & 1.44 \\
\hline Wood Processing Industry & 3.62 & 2.20 & -2.30 & -1.60 & 0.87 & -3.43 & -0.01 & 2.39 \\
\hline $\begin{array}{l}\text { Paper Products, Printing and } \\
\text { Publishing Industry }\end{array}$ & 4.87 & 2.30 & -2.49 & -1.21 & 1.35 & -3.15 & -0.74 & 1.92 \\
\hline Metal Products Industry & 7.31 & -2.29 & -5.45 & 1.28 & 0.19 & -3.90 & 0.12 & 2.34 \\
\hline Motor Vehicles and Spare Parts & -5.67 & -5.20 & -6.88 & -4.55 & 1.60 & 6.04 & 3.81 & 1.84 \\
\hline $\begin{array}{l}\text { Other Transportation Equipment } \\
\text { Manufacturing }\end{array}$ & 2.48 & -6.99 & -26.48 & -7.22 & 2.43 & 6.70 & 41.58 & 3.88 \\
\hline Other Light Industry & 5.54 & -2.49 & -4.98 & 0.90 & 0.95 & -4.78 & -0.33 & 1.63 \\
\hline $\begin{array}{l}\text { Chemical Rubber and Plastic } \\
\text { Products }\end{array}$ & 4.21 & -6.46 & -6.87 & -1.65 & 2.29 & 11.94 & 6.72 & 2.83 \\
\hline Ferrous Metal Smelting & 2.95 & -3.62 & -3.78 & -45.00 & -0.28 & -2.88 & 0.31 & 0.80 \\
\hline Non-ferrous Metal Industry & 6.49 & -8.84 & -4.73 & -21.01 & 0.22 & -3.76 & 0.20 & -0.11 \\
\hline $\begin{array}{l}\text { Electronic Equipment } \\
\text { Manufacturing }\end{array}$ & -12.20 & -12.94 & -9.20 & -14.96 & 0.54 & -4.62 & 0.42 & 1.06 \\
\hline $\begin{array}{l}\text { Mechanical Equipment } \\
\text { Manufacturing }\end{array}$ & -5.91 & -1.32 & -5.58 & -13.80 & 0.65 & -4.50 & 0.20 & 2.15 \\
\hline $\begin{array}{l}\text { Oil, Coal and Other Mining } \\
\text { Industry }\end{array}$ & 1.83 & 0.86 & -1.26 & -1.00 & -0.13 & -0.76 & 0.01 & 1.24 \\
\hline $\begin{array}{l}\text { Electricity Production and } \\
\text { Supply }\end{array}$ & 4.68 & 1.25 & -2.30 & -0.99 & -1.01 & -3.41 & 0.43 & 1.66 \\
\hline Construction Industry & 4.85 & 2.17 & -4.20 & -5.00 & -0.34 & -2.84 & 1.02 & 2.39 \\
\hline $\begin{array}{l}\text { Water Gas Production and } \\
\text { Supply }\end{array}$ & 6.97 & 2.73 & -3.76 & -1.22 & -0.29 & -4.35 & 0.23 & 2.23 \\
\hline Communications Industry & 5.49 & 1.49 & -3.23 & -0.91 & -0.13 & -2.77 & 0.20 & 1.34 \\
\hline Transportation Industry & 3.08 & 1.54 & -2.94 & -1.24 & 0.26 & -1.97 & 0.24 & 1.34 \\
\hline Financial Insurance Industry & 5.94 & 2.74 & -3.67 & -1.92 & -0.15 & -2.62 & 0.30 & 1.64 \\
\hline Business Service & 5.28 & 2.15 & -3.24 & -1.08 & 0.15 & -2.84 & 0.22 & 1.52 \\
\hline Entertainment Industry & 5.33 & 2.36 & -2.92 & -1.54 & 0.30 & -2.48 & 0.08 & 1.41 \\
\hline Other Service Industry & 5.59 & 2.25 & -3.34 & -0.30 & 0.20 & -2.47 & 0.10 & 0.93 \\
\hline
\end{tabular}

Note: Change of the cumulative rate (\%) by 2020 compared to the basic scenario.

Data source: GTAP model simulation results.

\subsection{Impact on Added Value of Major Industries in China and US}

Under the trade friction escalation scenario, the added value of China's motor vehicles and spare parts, ferrous metal smelting, non-ferrous metals industry, electronic equipment manufacturing, machinery and equipment manufacturing industry will be obviously affected by the increase in US tariffs. By 2020, added value of above five industries will fall by $0.29 \%, 0.47 \%, 0.12 \%, 7.36 \%$ and $1.80 \%$. It can be seen that in the context of traditional high-energy-consuming industries' capacity reduction, coupled with the longstanding trade friction in steel and aluminum products,
China's ferrous metal smelting and non-ferrous metals industry will be less affected. The high-tech industries such as electronic equipment manufacturing and machinery and equipment manufacturing are in rapid development, which will be greatly affected by higher tariffs. Meantime, due to the slowdown in domestic investment and consumption, oil, coal and other mining, construction and service industries will also suffer certain negative impact. In addition, China's counter-measures will have a positive impact on some industries, the added value of agriculture, livestock and meat products, food processing industry, light industry, chemical rubber and plastic products industry will increase.

Under the trade friction escalation scenario, for the US, the added value agriculture, livestock and meat products, motor vehicles and spare parts, other transportation equipment 
equipment manufacturing, chemical rubber and plastic products will rise by $1.82 \%, 0.71 \%, 1.70 \%, 3.22 \%$ and $3.59 \%$ respectively. Correspondingly, the added value of China's agriculture, livestock and meat products, motor vehicles and spare parts, other transportation equipment manufacturing, chemical rubber and plastic products, and electronic equipment manufacturing will fall by $1.53 \%, 0.14 \%, 0.83 \%$, $3.88 \%$, and $1.48 \%$ by 2020 . The added value of China's high-tech industries such as electronic equipment manufacturing and machinery and equipment manufacturing will increase by $0.50 \%$ and $0.39 \%$ respectively, providing developing space for the "Made in China 2025" strategy. of US agricultural products, livestock and meat products, motor vehicles and spare parts, other transportation

Table 5 The impact of trade friction on major industries of China and US

\begin{tabular}{|c|c|c|c|c|}
\hline \multirow{2}{*}{$\frac{2020}{\text { Industry }}$} & \multicolumn{2}{|c|}{$\begin{array}{c}\text { Trade Friction } \\
\text { Escalation Scenario } \\
\end{array}$} & \multicolumn{2}{|c|}{$\begin{array}{c}\text { Trade Friction } \\
\text { Mitigation Scenario }\end{array}$} \\
\hline & $\begin{array}{c}\text { Added Value } \\
\text { in China }\end{array}$ & $\begin{array}{c}\text { Added Value } \\
\text { in US }\end{array}$ & $\begin{array}{c}\text { Added Value } \\
\text { in China }\end{array}$ & $\begin{array}{c}\text { Added Value } \\
\text { in US }\end{array}$ \\
\hline Agriculture & 1.93 & -2.07 & -1.53 & 1.82 \\
\hline Livestock and Meat Products & 0.66 & -0.28 & -0.14 & 0.71 \\
\hline Coal & 0.15 & -0.01 & 0.00 & -0.10 \\
\hline Oil & 0.09 & -0.01 & 0.00 & -0.10 \\
\hline Natural Gas & 0.04 & 0.02 & -0.07 & 0.00 \\
\hline $\begin{array}{l}\text { Forestry, Fisheries and Other } \\
\text { Mining Industry }\end{array}$ & 0.32 & -0.14 & 0.06 & -0.19 \\
\hline Food Processing Industry & 0.29 & -0.01 & 0.42 & -0.45 \\
\hline Textile and Clothing Industry & 1.69 & 0.03 & 1.12 & -1.47 \\
\hline Leather Industry & 1.63 & 0.55 & 1.12 & -3.58 \\
\hline Wood Processing Industry & 1.62 & -1.93 & 0.62 & -0.16 \\
\hline $\begin{array}{l}\text { Paper Products, Printing and } \\
\text { Publishing Industry }\end{array}$ & 0.56 & 0.24 & 0.32 & -0.40 \\
\hline Metal Products Industry & 0.71 & -1.04 & 0.20 & -0.63 \\
\hline Motor Vehicles and Spare Parts & -0.29 & -2.08 & -0.83 & 1.70 \\
\hline $\begin{array}{l}\text { Other Transportation Equipment } \\
\text { Manufacturing }\end{array}$ & 2.45 & -3.52 & -3.88 & 3.22 \\
\hline Other Light Industry & 1.53 & -2.22 & 0.45 & -1.95 \\
\hline $\begin{array}{l}\text { Chemical Rubber and Plastic } \\
\text { Products }\end{array}$ & 2.02 & -2.03 & -1.48 & 3.59 \\
\hline Ferrous Metal Smelting & -0.47 & 8.46 & 0.14 & -1.43 \\
\hline Non-ferrous Metal Industry & -0.12 & 3.70 & 0.20 & -2.60 \\
\hline $\begin{array}{l}\text { Electronic Equipment } \\
\text { Manufacturing }\end{array}$ & -7.36 & 8.82 & 0.50 & -2.19 \\
\hline $\begin{array}{l}\text { Mechanical Equipment } \\
\text { Manufacturing }\end{array}$ & -1.80 & 1.97 & 0.39 & -2.00 \\
\hline $\begin{array}{l}\text { Oil, Coal and Other Mining } \\
\text { Industry }\end{array}$ & -0.40 & -0.15 & 0.21 & 0.21 \\
\hline $\begin{array}{l}\text { Electricity Production and } \\
\text { Supply }\end{array}$ & 0.14 & 0.15 & -0.05 & 0.06 \\
\hline Construction Industry & -1.76 & -3.09 & 0.84 & 0.69 \\
\hline $\begin{array}{l}\text { Water Gas Production and } \\
\text { Supply }\end{array}$ & 0.06 & 0.07 & 0.15 & 0.04 \\
\hline Communications Industry & -0.39 & -0.17 & 0.25 & -0.07 \\
\hline Transportation Industry & -0.22 & -0.05 & 0.23 & -0.01 \\
\hline Financial Insurance Industry & -0.30 & 0.03 & 0.15 & -0.09 \\
\hline Business Service & -0.38 & 0.01 & 0.27 & -0.20 \\
\hline Entertainment Industry & -0.06 & 0.03 & 0.31 & -0.01 \\
\hline Other Service Industry & -0.13 & -0.02 & 0.31 & 0.01 \\
\hline
\end{tabular}


[5] Wang Jiaqiang, Wang Youxin. The Impact of Trump's New Deal on Sino-US Economy[J]. Tsinghua Financial Review, 2017(02): 105-109.
Although the US can reduce trade deficit in the short-term under trade friction escalation scenario, the reduction in deficit is achieved by faster decline of imports than that of exports. Meantime, consumption, investment, employment, and economic growth in the US will suffer. This is contrary to Trump's intention to increase trade surpluses through trade protection to promote economic growth and employment.

Under the trade friction mitigation scenario, China's increase in imports from the US can reduce the US deficit with China, but it is difficult to achieve the goal of reducing the total deficit globally. Because of the substitution effect, China will reduce imports from other trading partners, lowering the economic growth of other countries, thus affecting US exports to these countries. In the end, the growth rate of US export growth is smaller than that of import growth. The US trade deficit expand slightly, but its consumption, investment, employment, and economic growth all will be accelerated.

From the perspective of industry development, China's traditional high-energy-consuming industries will be only slightly impacted in the trade friction escalation scenario, which is related to China's supply-side structural reform. The traditional industry already achieved remarkable effect in capacity reduction, and the growth rate of exports has declined, so it is less affected by trade friction. China is in a critical period of conversion between old and new kinetic energy. The rapid development of high-tech industries has become a new growth point for the economy and an important starting point to achieve high-quality development. The escalation of trade friction will have a greater negative impact on China's high-tech industry. The trade friction mitigation scenario can achieve a win-win situation between China and the US, providing developing space for China's high-tech industry, providing conditions for the conversion of new and old kinetic energy and achieving high-quality development.

\section{ACKNOWLEDGMENT}

This paper is supported by the Science and Technology Project of State Grid Corporation of China (Research on key issues of medium and long-term electric power development).

\section{REFERENCES}

[1] Huang Xinmiao Zhang Yingying. Trump Trade Policy and Its Impact on China [J]. Rural Economy and Technology, 2017, 28 (09): 133-136.

[2] Wang Kaile. The development trend of new trade protectionism and China's foreign trade countermeasures [J]. China Business Theory, 2017 (05): 77-78.

[3] Han Bett. Trump Administration's Foreign Trade Policy and the Development of Sino-US Trade Relations [J]. China Business Theory, 2017 (22): 68-71.

[4] Wu Jiansheng, Jin Ruiting, Yao Shumei. Characteristics, Influences and Countermeasures of Trump's New Economic Policy [J]. China Development Review, 2017(06): 53-56. 